\title{
Study of population dynamics of the olive fruit fly Bactrocera oleae (Diptera, Tephritidae); (rossi, 1790) in the Mezghenna area
}

\author{
A. Achouche ${ }^{12 *}$, F. Abbassi ${ }^{1}$, A. Benzahra ${ }^{1}$, Z. Djazouli ${ }^{2}$ \\ ${ }^{1}$ Department of Agricultural and Forestry Zoology, Ecole Nationale Supérieure Agronomique, Avenue Hassan Badi El \\ Harrach Algiers, Algeria. \\ ${ }^{2}$ Department of Sciences of Nature and Life, Biotechnology Laboratory of Plant Productions, University of Blida 1. B.P. \\ 270 Soumaa Road; Ouled Yaich Blida, Algeria. Tel: (213) 238285 07/12 \\ E-mail: Myriapode1991@gmail.com
}

Received: 03.10.2019. Accepted: 30.10.2019

\begin{abstract}
The population dynamics of the Olive Fruit Fly in the Tell Atlas has been studied for two years (May 2017-April 2019) on all phases of olive tree growth. The test was installed on an individual farm in the Mezghenna region. It is part of the ongoing work to assess the damage caused by the diptera Bactrocera oleae.

The objective of this study is to collect information on adult flight and to calculate the population index (FTD) . On the other hand, we studied the annual variation of this last.

The results of this study show that the olive fruit fly population fluctuates over time and from one period to another in the study area; Overall, we recorded a low density of Bactrocera oleae during the first year of study (less than 0.008 flies / trap / day). In addition, in the second year, we observed 3 population peaks concentrated in autumn and early spring; the high temperatures of summer have a negative effect on the density of the Diptere.

Key words: Olive fruit fly; tell atlas; Mezghenna; Bactrocera oleae
\end{abstract}

\section{Introduction}

The olive tree (Olea europaea) is one of the most characteristic trees in the Mediterranean region; it is of great nutritional, social, cultural and economic importance to the stands in this region where it is widely distributed (Claridge and Walton 1992).

This crop is confronted with diseases and attacks of many insects. The olive fruit fly is undoubtedly among the main pests which cause damage as much qualitative (Cimato, 1990) as quantitative (Delrio, 1995) on the olive production.

Endophytes, larvae of the olive fruit fly develop in the tissues of fruit (Arambourg 1986).

The activity of Bactrocera is influenced by several factors including latitude, altitude, tree load, irrigation, (Neuenschwander et al.,1986), temperature (Raspi et al 2005; Genç 2008), relative humidity (Broufas, 2009), variety (Rizzo 2006), physicochemical characteristics of drupe (Mraicha, 2010) and parasite activity (Kapaun et al 2010) etc.

Classified as a quarantine pest in international trade in agricultural products, the olive fruit fly is a factor limiting fruit exports for some countries and increases their export costs due to the disinfection treatments applied. Losses due to damage caused by Tephritidae and especially olive fruit flies are estimated worldwide at several billion dollars according to (Norrbom 2004).

Compare to the olive fruit fly's aggression mode, the control of this pest is all the more complex as conventional chemical control remains ineffective in controlling their damage and has harmful effects on the environment, producers and consumers.

Faced with this situation and to improve the methods of fight against these pest, many studies around the world have been devoted to the knowledge of these insect in terms of their systematic, their biology, their ecology, their ethology and control (Boumezzough 2015, Nardi et al 2005, Vontas et al 2002, Alberola et al 1999, Katsoyannos et al 2001, Bueno et al 2002, Saour and Makee 2004, Kakani et al, 2010, Broumas et al. al, 2002;), particularly in algeria (Achouche, 2019, Senouci et al 2019, Medjkouh et al, 2018, Medjkouh et al, 2016, Ilias et al 2013, Tamendjari et al 2004).

In the subhumid climate (in Algeria), the study of the population dynamics of Bactrocera oleae is not very well known. For these reasons, we have found it important to follow the evolution of the populations of this insect over time in the Mezghenna region and to try to identify some factors that may play a role in the population dynamics of this devastator.

\section{Materials and methods}

\section{Study site ( Table 1, Figure 1, Figure 2).}

The dynamic population of olive fruit flies in the Mezghenna region were studied for two years (May 2017-April 2019), the biotic and abiotic characteristics of the study orchard are shown in ( Table 1).

Table 1. The biotic and abiotic characteristics.

\begin{tabular}{lllllll}
$\begin{array}{l}\text { Surface } \\
\text { of the } \\
\text { site }\end{array}$ & GPS Data & $\begin{array}{c}\text { Altitude } \\
\text { (metre) }\end{array}$ & $\begin{array}{l}\text { Remote from } \\
\text { the sea ( } \\
\mathbf{K m} \text { ) }\end{array}$ & $\begin{array}{l}\text { Distance } \\
\text { between } \\
\text { trees } \\
\text { (mètre) } \\
6 * 6 \mathrm{~m}\end{array}$ & $\begin{array}{l}\text { Type of } \\
\text { tree } \\
\text { rows }\end{array}$ & $\begin{array}{l}\text { Condition of study site } \\
\text { Regular }\end{array}$ \\
$\begin{array}{lllll}36^{\circ} 20^{\prime} 34^{\prime \prime} \mathrm{N} \\
3^{\circ} 19^{\prime} 08^{\prime \prime} \mathrm{E}\end{array}$ & $650 \mathrm{~m}$ & $50 \mathrm{~km}$ & $\begin{array}{l}\text { Olive grove uni-varietal } \\
\text { (olive oil) }\end{array}$ \\
\hline
\end{tabular}


Annual tree size

Absence of phytosanitary treatment.

Very high density of trees

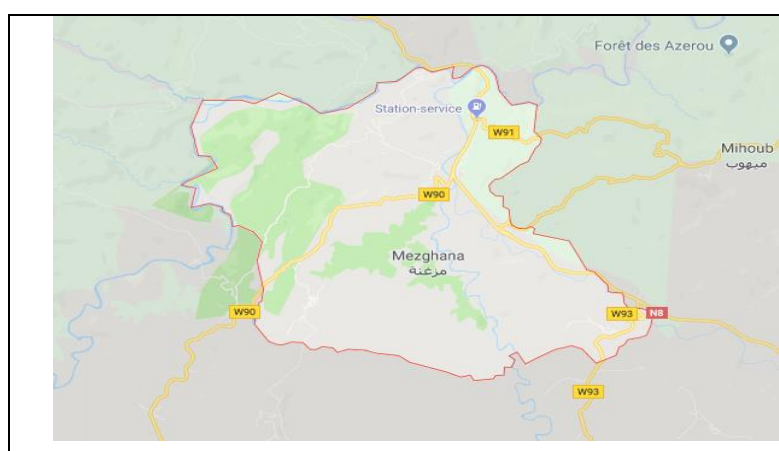

Figure 1 : The Mezeghenna area

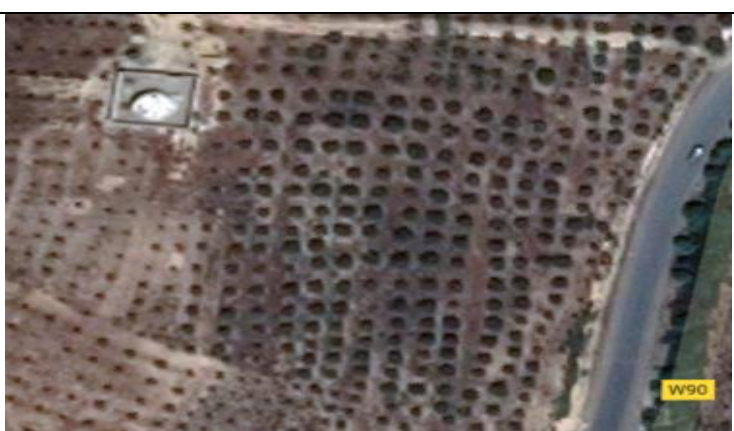

Figure 2 : Olive grove of Mezghenna

\section{Climate of Mezeghenna (Table 2).}

The climate here is classified as Csa by the Köppen-Geiger climate classification. The average temperature in Mezeghenna is $15.7^{\circ}$ C. each year, Rainfall averages $641 \mathrm{~mm}$ per year (https://fr.climate-data.org).

Table 2. monthly change in temperature and precipitation.

\begin{tabular}{llll} 
Month & $\begin{array}{l}\mathbf{T} \text { min } \\
\left(\mathbf{C}^{\circ}\right)\end{array}$ & $\begin{array}{l}\mathbf{T} \text { max } \\
\left(\mathbf{C}^{\circ}\right)\end{array}$ & $\mathbf{P}(\mathbf{m m})$ \\
January & 3.9 & 12.2 & 111 \\
February & 4.8 & 13.6 & 74 \\
March & 6.6 & 15.7 & 66 \\
April & 8.7 & 18.5 & 50 \\
May & 11.8 & 22 & 44 \\
June & 15.6 & 26.1 & 22 \\
July & 18.3 & 30 & 3 \\
August & 18.7 & 30.4 & 4 \\
September & 17.1 & 26.8 & 30 \\
October & 12.6 & 21.9 & 51 \\
November & 8.3 & 16.7 & 80 \\
Décember & 4.9 & 13.2 & 106 \\
\hline
\end{tabular}

\section{The adult population level estimate}

Since the colonial era, the estimate of the level of the population of the olive fruit fly Bactrocera oleae is the subject of many researches in Algeria (Martin h, 1952; Hobaya et al, 2012, Achouche et al, 2017; Gaouar and Debouzie, 1991).

The detection of this pest is essential to effectively control their population in the olive groves. We must anticipate to manage the pest population ecologically by restricting the use of pesticides or to biologically control them. Which means, that several trapping techniques are presented to examine the dynamic of population of Bactrocera oleae.

In our study we used yellow food with side holes of about $1 \mathrm{~cm}$, each contained a solution of Nitrogen Fertilizer (Urea Nitrogen 46 unit) of $0.3 \%$, hung from the branches of the trees (Please indicate how many traps were placed in total and how many trees.). The traps were placed inside the trees under the shade of the branches, and they were visited three to four times per month during the entire period of study, which took place between June 2017 and May 2018.

It is significantly important that he traps density matches the prospecting goals, which will determine the confidence that can be placed on the results of the research (CIPV, 2016).

In our study, we placed four food traps in each olive grove; the selection of soluble product is based on the efficiency and the availability of the latter.

According to CIPV (2016), the frequency of traps maintenance is based on the fig Half-life of the attractive, knowing that the actual duration must be confirmed by examinations in the field. The maintenance of the traps includes re-baiting and maintenance of the trap in a state of appropriate cleanliness that allows proper functioning.

The rate of release is generally high in hot and drought areas, and tends to worsen in humid and cooler areas. Therefore, traps maybe re-baited less often than in hot conditions.

\section{Calculate and estimate the index of the FTD population}

The numbers (Abundances) of the olive fruit flies captured by the traps in different locations of Mezghenna region during the the whole study period, gave access to assess the pest prevalence (FTD) according to the formula below (IAEA, 2003). In fact, the prevalence is equal to the average number of individuals captured in one day. 
$\mathrm{F}=$ the total number of captured flies,

T=number of inspected traps,

$\mathrm{D}=$ number of days during which traps have been exposed on the field.

$$
\mathrm{FDT}=\mathrm{F} / \mathrm{T} \times \mathrm{D}
$$

Monitoring of the fluctuation of the population index, helped to identify the proliferation of the latter.

\section{Results and discussion}

Annual estimate of the FTD Population Index ( Table 3, Figure 3) :

The use of food traps has allowed the capture of adults of the olive fruit fly, which provides information on kinetics, pest attacks, date of emergence or appearance of a new generation, represented by a peak of population, which makes it possible to estimate the number of generations during the study period.

The analysis of the variance of the FTD showed a highly significant difference $(<0.01)$ between the two years of study. The rate of FTD values in the first year (May 2017-April 2018) showed a low appearance of olive fruit fly with a value lower than (0.008 fly/trap/day); In addition, in the second year (May 2018-April 2019) the FTD observation showed a low activity of Bactrocera oleae during Winter, Spring and Summer with a value lower than ( $0.5 \mathrm{fly} / \mathrm{trap} / \mathrm{day})$. On the other hand, the maximum values are recorded in Autumn with a value higher than ( 0.7 fly/trap/day).

Table 3. Estimate the index of the FTD population.

\begin{tabular}{llll}
\hline Year & FTD & \multicolumn{2}{l}{ Analysis of variance } \\
A1 (May 2017;April2018) & 0,007 & $\mathrm{~F}$ & $\mathrm{P}$ \\
A2 (May 2018;April2019) & 0,319 & 13,63 & $0 * * *$ \\
\hline
\end{tabular}

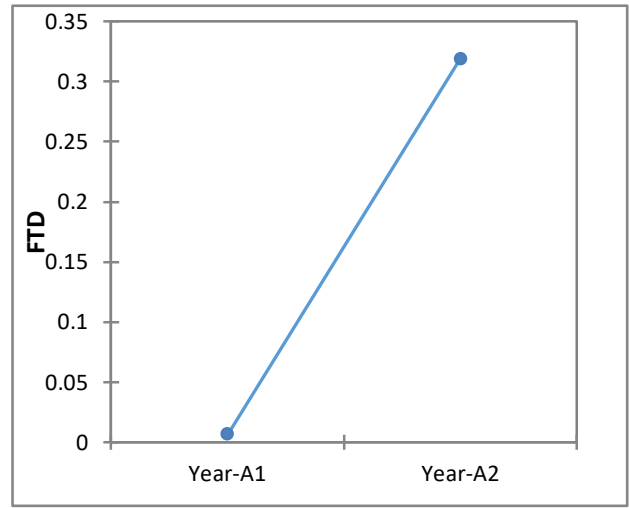

Figure 3. Annual change in the FTD (population index).

\section{Population dynamics of the olive fruit fly (May 2017-April 2018). (Table 4, Figure 4 ).}

Analysis of the FTD (population index) curve of adults of Bactrocera oleae, shows three (3) population peaks with a very low density. The first peak is in May with (0.08 flies/trap/day; 2.4 flies/trap/month), the second peak is in October with (0.03 flies/trap/day; 1 fly/trap/month). The third population peak was observed in April with (0.02 fly/trap/day;<a 1 fly/trap/Month).

\section{Population dynamics of the olive fruit fly (May 2018-April 2019).( Table 4; Figure 5).}

In the second year the FTD observation showed (3) population peaks with a higher density. The first peak was observed in September with (1.4 fly/trap/day; 42 flys/trap/month), the second peak takes place in November with (1.08 fly/trap/day; 32 flys/trap/month). In spring a third peak appeared in March with (0.46 flys/trap/day; 14 flies/trap/month).

Table 4. Change in the population index (May 2017-April 2019); ** Peak of population.

\begin{tabular}{llllll}
\hline Year & Month & FTD & Year & Month & FTD \\
A1 & May-17 & $0.08^{\star *}$ & A2 & May-18 & 0.03 \\
A1 & Jun-17 & 0 & A2 & Jun-18 & 0 \\
A1 & Jul-17 & 0 & A2 & Jul-18 & 0 \\
A1 & Aug-17 & 0 & A2 & Aug-18 & 0.02 \\
A1 & Sep 17 & 0 & A2 & Sep 18 & $1.44^{* *}$ \\
A1 & Oct 17 & $0.03^{\star *}$ & A2 & Oct 18 & 0.69 \\
A1 & Nov 17 & 0.01 & A2 & Nov 18 & $1.08^{* *}$ \\
A1 & Dec 17 & 0 & A2 & Dec 18 & 0.28 \\
\hline
\end{tabular}




\begin{tabular}{llllll}
\hline A1 & Jan-18 & 0 & A2 & Jan-19 & 0.09 \\
A1 & Feb-18 & 0 & A2 & Feb-19 & 0.15 \\
A1 & Mar-18 & 0 & A2 & Mar-19 & $0.46^{\star *}$ \\
A1 & Apr-18 & $0.02^{\star *}$ & A2 & Apr-19 & 0.14 \\
\hline
\end{tabular}

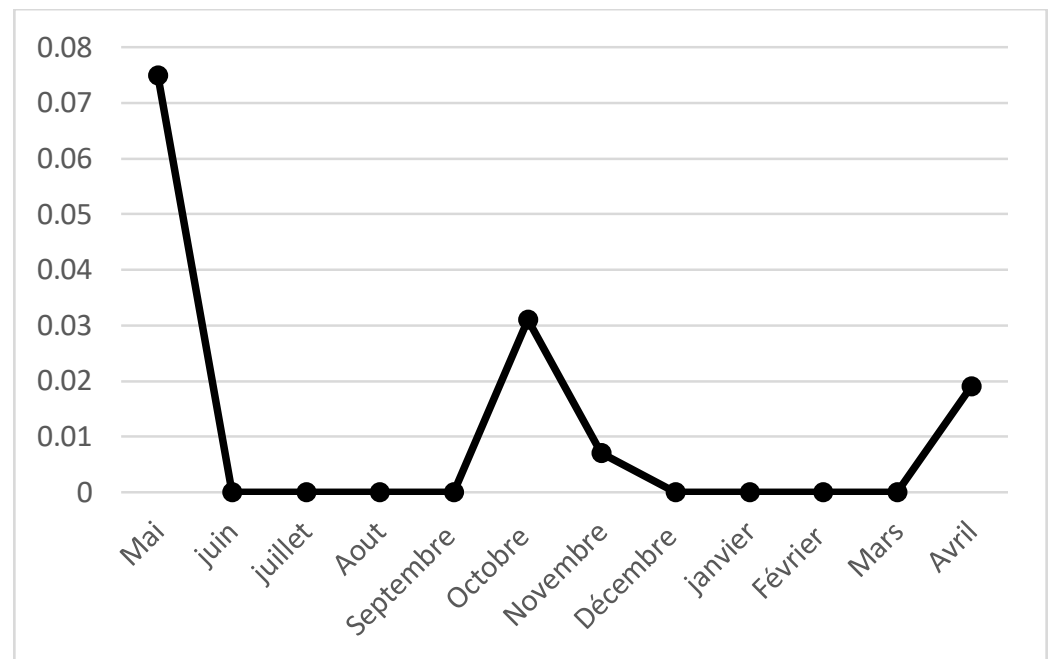

Figure 4. Change in the population index ( $A 1=$ May 2017, April 2018).

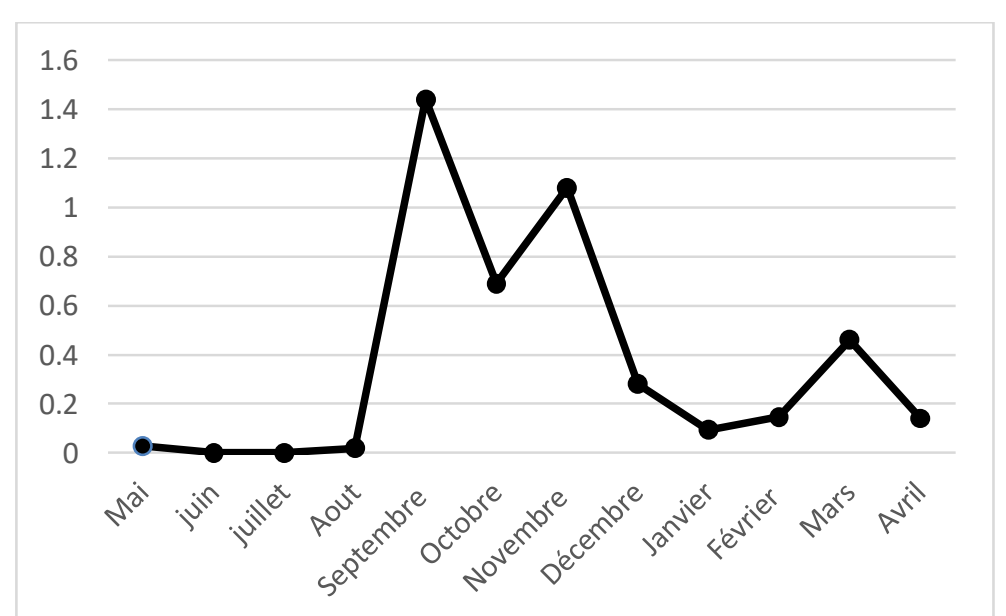

Figure 5. Change in the population index ( $A 2=$ May 2018, April 2019).

\section{Discussion}

The results of this study show that the population of Bactrocera oleae fluctuates over time and from one period to another in the study area. This result is consistent with (Kanta et al 2015) which shows that the fluctuation in time and space of Bactrocera dorsalis is related to host availability and variation in different climatic factors.

the development of population of this species (higher temperature $28^{\circ} \mathrm{C}$ ). Moreover, average temperatures have a positive influence on the activity of the Diptera (temperature between $17^{\circ} \mathrm{C}$ and $27^{\circ} \mathrm{C}$ ).

According to (Bateman1972), temperature has an important role in the abundance of the Tephritidae through its effect on rates of development, of mortality and fertility of these insects. Bactrocera oleae is an insect that grows in average weather conditions. (Raspi et al , 2005) concluded that the best temperature for the development of the olive fruit fly is between $20^{\circ} \mathrm{C}$ and $26^{\circ} \mathrm{C}$

Indeed, rates of growth and decline of these populations are dependent on temperature, where multiple influences effect on individuals of the population and their lifestyle.

(Neuenschwander et al, 1979) estimated that temperature above $30^{\circ} \mathrm{C}$ cause resorption of ovarian follicles by reducing the fecundity of the olive fruit fly females which causes a decline in population. Several studies were conducted in this sense, (Abdelli , 1996) found that temperature could be responsible for the difference in levels of infestation observed in Mediterranean fruit fly. Low temperatures especially if associated with heavy rains increase significantly the mortality of adults. Upper and lower limits for the development of the medfly are respectively $35^{\circ} \mathrm{C}$ and $9^{\circ} \mathrm{C}$ (Bodenheimer, 1951).

On the other hand, according to (Ouedraogo, 2011), relative humidity has not only a direct impact on the demography of species, but also an indirect effect through its influence on host plants and natural enemies. The relative humidity of the environment is particularly important in the abundance of Tephritidae by reducing the fertility of female adults in dry period, and the high mortality of newly emerged adults. Moreover, low relative humidity reduces the longevity of the fruit fly adults (Bateman,1972). Monitoring the activity of adult fly through the catch followed by installation of pheromone traps or food can detect theft and avoid big surprise outbreak of the fly and large infestations. The determination of the control elements of bio-ecology of Bactrocera oleae 
fly and population dynamics of the various stages of its development cycle can help to consider a good strategy against the fly in the study area. The fight against the pest requires 2-3 treatments per year depending on the degree of infestation and the climatic conditions. During harvest, it is highly recommended to replace the techniques of shaking down which causes injury fruit and causes biochemical alterations making the oil unstable with increasing acidity. The decision of the harvest date should consider the maturity index of the olives and the state of adult dynamics of the fly to avoid over-infestation by last autumn generations.

According to the literature, phytosanitary intervention attempts are poor and insecticide applications are recorded but are random and not based on knowledge of the pest and its development cycle (Ougass, y. 2012).

\section{Acknowledgement}

We thank God for grace.

Then we thank everyone who contributed from near or far to complete this research.

\section{References}

Abdelli, O. (1996). Etude de quelques aspect de la bio-écologie de la mouche méditerranéenne des fruits Ceratitis capitata (Wiedemann, 1824),(Diptera: Trypetidae) dans le parc de Chaib(Doctoral dissertation, Thèse. Mag. Inst. Sc. Nat., Uni. Tizi Ouzou). Achouche, A., Abbassi, F., Benzahra, A., Djazouli, Z. (2019). Study of some demographic parameters of Bactrocera (Dacus oleae); Test of a new food attractant in a trapping method. Ukrainian Journal of Ecology. 9(3) : 13-20.

Achouche, A., Djazouli, Z., Abbassi, Fethi. (2017). Observation écologique des dégâts provoqués par la Mouche d’olive Bactrocera oleae ( Diptera, Tephritidae) .Premier Symposium Mghrébin sur la protection intégrée des Plantes .

Alberola, T. M., Aptosoglou, S., Arsenakis, M., Bel, Y., Delrio, G., Ellar, D. J., Martínez-Sebastián, M. J. (1999). Insecticidal activity of strains of Bacillus thuringiensis on larvae and adults of Bactrocera oleae Gmelin (Dipt. Tephritidae). Journal of Invertebrate Pathology. 74(2) : 127-136.

Arambourg, Y. (1986). Traité d'entomologie oléicole. Ed. Conseil oléicole international Juan Bravo, Madrid, 360.

Bateman, M.A. (1972). The ecology of fruit flies. Annual Review of Entomology. 17: 493-518.

Ouedraogo, S. (2011). Dynamique spatio-temporelle des mouches des fruits (Diptera Tephritidae) en fonction des facteurs biotiques et abiotiques dans les vergers de manguiers de l'Ouest du Burkina. These de Doctorat, Paris Est184. Biologicaland Chemical Sciences. 9(6): 2698-2715.

Broufas, G. D., Pappas, M. L., Koveos, D. S. (2009). Effect of relative humidity on longevity, ovarian maturation, and egg production in the olive fruit fly (Diptera: Tephritidae). Annals of the Entomological Society of America. 102(1) : 70-75.

Broumas, T., Haniotakis, G., Liaropoulos, C., Tomazou, T., Ragoussis, N. (2002). The efficacy of an improved form of the mass-trapping method, forthe control of the olive fruit fly, Bactrocera oleae (Gmelin)(Dipt., Tephritidae): pilot-scale feasibility studies. Journal of Applied Entomology. 126(5): 217-223.

Bueno, A. M., Jones, O. (2002). Alternative methods for controlling the olive fly, Bactrocera oleae, involving semiochemicals. IOBC wprs Bulletin. 25(9): 147-156.

CIVP . (2016). Établissement de zones exemptes de mouches des fruits (Tephritidae), FAO, NIMP $26: 64$.

Delrio, G., Lentini, A., Satta, A. (2005). Biological control of olive fruit fly through inoculative releases of Opius concolor Szépl. IOBC WPRS BULLETIN. 28(9): 53 .

Gaouar, N., Debouzie, D. (1991). Olive fruit fly, Dacus oleae Gmel (Diptera, Tephritidae) damage in Tlemcen region, Algeria. Journal of Applied Entomology. 112(1-5): 288-297.

Hobaya, O., Bendimerad, M. (2012). Contribution à l'étude des ravageurs de I'Olivier Olea europea a Tlemcen , Thèse ingéniorat, Université Abou Bekr Belkaid - Tlemcen, Algérie,87.

Ilias, F., Gaouar, N., Medjdoub, K., Awad, M. K. (2013). Insecticidal activity of Bacillus thuringiensis on larvae and adults of Bactrocera oleae Gmelin (Diptera: Tephritidae). Journal of Environmental Protection. 4(05): 480.

IAEA. (2003). Trapping guidelines for area-wide fruit fly programmes. International Atomic Energy Agency, Vienna, Austria, 47.

Gomina, M. (2015). Contribution à la connaissance des mouches des fruits (Diptera: Tephritidae) et de leurs parasitoïdes au sud du Togothèse doctorat en sciences de la vie, Spécialité : Biologie de développement, Option : Entomologie Appliquée, Universite de Lome-Togo,190.

Kakani, E. G., Zygouridis, N. E., Tsoumani, K. T., Seraphides, N., Zalom, F. G., Mathiopoulos, K. D. (2010). Spinosad resistance development in wild olive fruit fly Bactrocera oleae (Diptera: Tephritidae) populations in California. Pest Management Science: formerly Pesticide Science. 66(4): 447-453.

Kapaun, T., Nadel, H., Headrick, D., Vredevoe, L. (2010). Biology and parasitism rates of Pteromalus nr. myopitae (Hymenoptera: Pteromalidae), a newly discovered parasitoid of olive fruit fly Bactrocera oleae (Diptera: Tephritidae) in coastal California. Biological control. 53(1): 76-85.

Katsoyannos, B. I., Kouloussis, N. A. (2001). Captures of the olive fruit fly Bactrocera oleae on spheres of different colours. Entomologia Experimentalis et Applicata. 100(2): 165-172.

Konta, I. S., Djiba, S., Sane, S., Diassi, L., Ndiaye, A. B., Noba, K. (2015). Etude de la dynamique de Bactrocera dorsalis (Hendel)(Diptera: Tephritidae) dans les vergers de mangues en Basse Casamance: influence des facteurs climatiques. International Journal of Biological and Chemical Sciences. 9(6): 2698-2715.

Martin, H. (1952). Contribution à l'étude de la mouche de l'olive Dacus oleae Rossi (Dipt. Trypetid.) en Algérie et en Provence . Bulletin de la société entomologique suisse, 9.

Medjkouh, L., Tamendjari, A., Alves, R. C., Araújo, M., Oliveira, M. B. P. (2016). Effect of Bactrocera oleae on phenolic compounds and antioxidant and antibacterial activities of two Algerian olive cultivars. Food \& function. 7(10): 4372-4378. Medjkouh, L., Tamendjari, A., Alves, R. C., Laribi, R., Oliveira, M. B. P. (2018). Phenolic profiles of eight olive cultivars from Algeria: effect of Bactrocera oleae attack. Food \& function. 9(2): 890-897.

Mraicha, F., Ksantini, M., Zouch, O., Ayadi, M., Sayadi, S., Bouaziz, M. (2010). Effect of olive fruit fly infestation on the quality of olive oil from Chemlali cultivar during ripening. Food and Chemical Toxicology. 48(11): 3235-3241

Nardi, F., Carapelli, A., Dallai, R., Roderick, G. K., Frati, F. (2005). Population structure and colonization history of the olive fly, Bactrocera oleae (Diptera, Tephritidae). Molecular Ecology. 14(9): 2729-2738.

Neuenschwander, P., Michelakis, S. (1979). Determination of the lower thermal thresholds and day-degree requirements for eggs and larvae of Dacus oleae (Gmel.)(Diptera: Tephritidae) under field conditions in Crete, Greece. Bul.Soc. Ent. Suisse. 52: 57-74. 
Gaouar Benyelles, N. (1989). Contribution à l'Etude de l'infestation de l'Olive par Dacus Oleae Gmel dans la Wilaya de Tlemen,thèse Magister ,Institut National D'Enseignement Supérieur de Biologie, 111.

Norbon .(2004). Fruit Fly (Diptera: Tephtitidae) Classification and diversity, Systematic and Entomology Laboratory, ARS, USDA, Department of entomology, NMNH, SI; The Diptera Site.

Ouedraogo, S. (2011). Dynamique spatio-temporelle des mouches des fruits (Diptera Tephritidae) en fonction des facteurs biotiques et abiotiques dans les vergers de manguiers de l'Ouest du Burkina. These de Doctorat, Paris Est,184.

Ougass, Y. (2012). Contribution à l'étude bioécologique de Sessetia oleae (Olivier) (Homoptera, Coccidae) dans les oliveraies d'Essaouira et la gestion des vergers oléicoles dans la région de Marrakech-Tensift-Al Haouz, Maroc. Ph.D. Thesis, Cadi Ayyad University, Faculty of Sciences Semlalia, Marrakech.

Mansour, A. A., Kahime, K., Chemseddine, M., Boumezzough, A. (2015). Study of the Population Dynamics of the Olive Fly, Bactrocera oleae Rossi.(Diptera, Tephritidae) in the Region of Essaouira. Open Journal of Ecology. 5(05): 174.

Raspi, A., Canale, A., Loni, A. (2005). Presence of mature eggs in olive fruit fly, Bactrocera oleae (Diptera Tephritidae), at different constant photoperiods and at two temperatures. Bulletin of Insectology. 58(2): 125.

Rizzo, R., Caleca, V. (2006). Resistance to the attack of Bactrocera oleae (Gmelin) of some Sicilian olive cultivars. In Proceedings of Olivebioteq 2006, Second International Seminar "Biotechnology and quality of olive tree products around the Mediterranean Basin" November 5th-10th, Mazara del Vallo, Marsala, Italy, 2: 291-298.

Saour, G., Makee, H. (2004). A kaolin-based particle film for suppression of the olive fruit fly Bactrocera oleae Gmelin (Dip., Tephritidae) in olive groves. Journal of Applied Entomology. 128(1): 28-31.

Senouci, H., Benyelles, N. G., Dib, M. E. A., Costa, J., Muselli, A. (2019). Essential Oil of Ammoides verticillata as Biocides for the Control of Fungal Infections and Devastating Pest (Bactrocera oleae) of olive tree. Recent patents on food, nutrition \& agriculture. Tamendjari, A., Angerosa, F., Bellal, M. M. (2004). Influence of Bactrocera oleae infestation on olive oil quality during ripening of Chemlal olives. Italian Journal of Food Science. 16(3).

Vontas, J. G., Hejazi, M. J., Hawkes, N. J., Cosmidis, N., Loukas, M., Hemingway, J. (2002). Resistance-associated point mutations of organophosphate insensitive acetylcholinesterase, in the olive fruit fly Bactrocera oleae. Insect molecular biology. 11(4): 329-336. (https://fr.climate-data.org).

\section{Citation:}

Achouche, A., Abbassi, F., Benzahra, A., Djazouli Z. (2019). Study of population dynamics of the olive fruit fly Bactrocera oleae (Diptera, Tephritidae); (rossi, 1790) in the mezghenna area. Ukrainian Journal of Ecology, 9(3), 309-314.

(cc) EY This work is licensed under a Creative Commons Attribution 4.0. License 